\title{
Teaching EFL in Saudi Arabian Context: Textbooks and Culture
}

\author{
Abdullah Saad Aldera \\ Najran University, Saudi Arabia
}

\begin{abstract}
This article analysed the impact of foreign (L2) cultures on EFL students in Saudi universities. The investigation has been carried out on the basis of theoretical background study, an analysis of the prescribed textbooks and a survey of the L2 learners' attitudes. The research samples include two course books, Access and Interaction1 published by McGraw-Hill Education, and students of English Department, Najran University, KSA. A thorough analysis of the contents of the series showed that the textbooks largely ignore local culture (L1) and include mainly foreign cultures and cultures of other nationalities. The overall results of the survey demonstrated thatL2 learners disagree with the dominance of foreign culture in their course books. However, they simultaneously showed a very positive attitude towards foreign cultures that do not contradict with Saudi social values. This article, therefore, sought to address the cultural bias in the course books and consequent grassroots discontent among L2 learners. The findings of the study are expected to help both ELT specialists and the concerned authority in KSA to select and design textbooks which are suitable for effective pedagogy and tolerably compatible with $\mathrm{L} 1$ values and culture.
\end{abstract}

Index Terms - textbooks, content analysis, L2 culture, teaching and pedagogy

\section{INTRODUCTION}

\section{A. Definition of Culture}

Culture may be defined as a manifestation of "the customs and beliefs, art, way of life and social organization of a particular country or group" (Hornby, p. 370). Culture emphasizes mutual interdependence of a people or different peoples bound by a moral, ethical, or religious system in order to continue their mutual co-existence. From this point of view, culture envisions a comprehensive mutual co-existence based on a sound and solid basis of cooperation and cohabitation in society at large.

As Kaikkonen (1994) has put it, "culture is a mutual agreement between the members of certain society about the values, rules, role expectations, and meanings, which direct the behavior of the members". Nieto (2010) adds that culture includes "a shared world-view, common history, geographic location, language, social class, and religion." Based on these definitions of culture, it can be concluded that everyone has a culture, because everyone has to be a part of it through social and political relationships. The culture of a group can, therefore, be defined as the relationship between its beliefs, values, behavior, and communication.

The Arabic word used for culture is al-thiqafa which means a collective achievement of the arts and manifestations of the human intellect. It focuses on such insight that guides people to acceptable and appropriate behavior in society. However, the domain of culture in Islam is entirely based on the teachings of the Holy Quran and the Sunnah of Prophet Muhammad (Peace be Upon Him). The Quran enjoins, "Ye have indeed in the Messenger of Allah a beautiful pattern (of conduct) for any one whose hope is in Allah and the Final Day, and who engages much in the Praise of Allah" (The Quran 33:21).Thus Islamic culture means a way of life and society defined, dictated, and guided by The Quran and Sunnah in local as well as international arena.

\section{B. Culture in Saudi Arabia}

Saudi Arabia was founded in 1932 by King Abdul Aziz bin Abdulrahman bin Al-Saud in the central part of Arabian Peninsula. The population of Saudi Arabia is about 30 million. Among them, around 18 million are Saudi citizens, who share Arabic language as their mother tongue and Islam as their only religion. Saudi Arabia is seen as the center of Islam as Islam was revealed by Allah to Prophet Muhammad (peace be Upon Him) in this land.

Although there are some small regional variations of cultural practices among Saudis in different areas, the overall scenario is homogenous and uniform. Despite the large number of expatriate workers with diverse cultural settings, a strict control is imposed on practices other than Islamic and Saudi culture. Thus Saudi Arabia tries hard to maintain the status quo where sociocultural norms are concerned. The over-all cultural patterns and behavior are defined and controlled by Islamic rules and regulations, along with the Saudi local traditions.

Saudi Arabia is a deeply religious country with a solid tradition of familial and tribal bond based on centuries-old Arab culture gradually fed by and merged into the spirit of Islam. As Ayubi (1994) has put it: "Islam is indeed very much a social region, seeking to organize the practice of social life, and above all the minute details of family life". As such, the law and customs of Saudi Arabia are based on Islamic values and the Sharia Law taught by Prophet 
Muhammad (Peace be Upon Him) more than 1400 years ago. Islamic rules and regulations are believed to be universally applicable, irrespective of time and place.

The religious people of this country try their best to follow the examples and commands of Prophet Muhammad (Peace be Upon Him). Some of these commands include prohibition of non-essential photography and segregation of sex. On Saturday, March 14, 2015, a piece of news was published in The Arab News in this context. According to the source, experts debated the issue of using animal images in school textbooks. According to Monotheism, which is taught to 12th grade students, photography is prohibited, while science books have plenty of images of humans and animals to explain anatomy. Students can see this stark contradiction when they read the Monotheism textbook, since in its pages, scholars strongly condemn the use of photography.

Another piece of news on violation of sex segregation published by the Arab News (March 18, 2015) is noteworthy in this connection. According to state law and tradition, men and women in the Kingdom have to be segregated in education and most fields of social activities in the country. Any violation of this practice is dealt with tough hand and severe punitive measures. However, a number people attempted to violate this rule which was strictly handled by the concerned authority. Citizens have been quoted as saying: "It is mandatory that all festivals in the Kingdom should have separate sections for men and women".

These incidents and social reactions reiterate the Kingdom's commitment to its tradition, culture, and values in the all arena of social and academic life.

\section{Textbooks and Culture}

A textbook is a standard work used for the study of a particular subject. Coursebooks usually function as a guide map for the ELT programs. According to Nunan (1988), textbooks form an important part of the teaching tools and function as standard models for classroom practice. They guide the L2 instructors through different phases of pedagogy to the culmination of their linguistic goal.

A textbook may include three types of cultural contexts. First of all, it may include the learner's own culture, which is also called the source culture. Secondly, it may solely include the foreign culture. And finally, it may include diverse cultural phenomena from both the local and native sources. However, most EFL/ESL textbooks usually include foreign culture, and local culture is rarely represented.

ELT textbooks are usually considered valid and labour-saving tools. However, in all types of set materials, learners have very little to do as they always swallow one-way flow of knowledge from the receivers' end. Throughout their learning process, students work out different tasks on selected materials that contain elements of foreign culture which are slowly, but gradually assimilated into their everyday life and consciousness. They hardly challenge the information they receive from the point of view of their own culture. Prospects for reciprocity are few and far between when text books are imposed on the learners and there is no possibility of change or modification. This may lead to a planned penetration of L2 culture into L1 domain in the name of L2 teaching worldwide.

EFL or ESL textbooks designed and produced in England or America mostly use events, incidents or actions which often carry target cultural view points on life and society and they profoundly affect the L2 learners' psychological and intellectual growth. Brumfit (1980) is a critic of such ELT coursebooks and calls them 'masses of rubbish... skilfully marketed'. Phillipson (1992) has contended that the main objectives behind the Britain-based the ELT materials are commerce and cultural domination. Abuelma'atti (2005) also argues that globalization may be seen from an economic angle as something promoted by western governments concerned with profits, leading to the spread and promotion of certain cultural and political agendas to best serve their economic objectives and interests.

According to Prodromou (1988), such enterprises dislocate the learners from their root culture and create a kind of alienation. Hyde (1994) has referred to Moroccan ELT instructors who are concerned with the effect of the declining faith among learners who are hardly able to meet the challenge of foreign cultures in academic arena.

There are now examples of countries around the world which are trying to preserve and maintain their own culture in ELT materials by changing their foreign language policies. Names of China, Venezuela, Morocco, Cameroon and Kuwait may be mentioned in this context. Scots (1980) has mentioned that Chinese EFL experts have reinforced Chinese norms and values in textbooks. According to Cortazzi and Jin (1999), the settings in Venezuelan textbooks refer to their own cities and events, with minor attention to places outside Venezuela. Hajjaji (1981) informs that ELT textbooks in Kuwait are being prepared with Kuwaiti situation in mind.

Thus Hayes and Schrier (2000) have put huge responsibility on concerned authority and experts who determine and implement language policy in any non-native contexts. Selectors in this case may consider the L2 learners' familiar cultural background. Teaching materials may include events, incidents and actions that correspond to the actual experiences or the potential experiences of the learners which will help them constructively utilize their previously acquired linguistic skills towards the achievement of the new and higher levels of acquisition.

Cultural bias or 'other' cultural dominance may potentially undermine the moral, ethical or religious values and traditions of the non-native nations concerned. The author of this article strongly believes that an intercultural approach in ELT may be more appropriate and appreciable for better understanding and mutual communications between different peoples of the world. But the burning questions are what categories of culture or what amount of culture or which country's culture---native or non-native---should in the classroom. This article seeks to answer all these questions. 


\section{LITERATURE REVIEW}

A lot of research regarding language teaching in recent years shows thatL2 pedagogy is heavily loaded with foreign cultural elements. Much of this has focused on debates about textbook selection in connection with language policy and principles. Such literature emphasizes awareness of the neo-imperialist agendas associated with the growth and spread of English as a global medium of communication (Pennycook, 1994; Phillipson 1992; Block and Cameron 2002).

The purpose of textbooks evaluation is to study the effects of the teaching materials on the particular learners concerned (Tomlinson, et al. 2001). The concerned authority thereby can measure the suitability of the coursebooks in use, so that maximum benefit may be reaped through substituting materials from other books (Cunningsworth, 1995).

Nault (2006) has opined that for useful and updated teaching tools, ELT specialists must take care in the selections of linguistic and cultural aspects in their texts. They should particularly think of the sensitivity of such selections as these materials have tremendous effects in shaping the academic as well as the intellectual growth of the learners out of the native context.

In his investigation of the effects of cultural aspects of British ELT textbooks, Gray (2006) interviewed a group of Barcelona-based teachers to know the content, range and role of target culture in ELT. The results show that they consider English as a lingua franca and the purpose is linguistic achievement, not any long-term cultural ambition. They all agreed on maximum exclusion of all irrelevant contents from the textbooks. They reached the consensus that the amount of cultural content to be included in coursebooks should be decided by the locals, not by the British ELT publishers.

Al Houssawi (2010)conducted an investigation into the perceptions of English language teachers of a western textbook called North Star in use in their Institution. The sample consisted of 35 male teachers who were already familiar with the textbook. The results showed that the subjects of the study had a negative perception of the cultural models and traditions provided by North Star coursebook. The data showed that the book lacked sufficient local culture and tradition. Moreover, the participants indicated that the course book failed to embody international cultures of English speakers. The study recommends adopting new cultural strategies to include both local and target cultures to enrich the content of the book.

Prodromou (1992) advocates cross-cultural approach in ELT course materials. In such an environment, he believes, learners can make a comparison and contrast between their own culture and 'other' cultures in the textbooks.

Therefore, on the basis of the results of different studies undertaken by different authors and specialists shown above, it may be concluded that neither the Middle East in general nor Saudi Arabia in particular has adopted any significant policy toward a culturally neutral or balanced approach to teaching English as a foreign language. As a result, the Saudi EFL learners show a negative attitude toward learning English as a foreign language.

\section{Methodology}

The research procedure has two parts: content analysis and survey. Access and Interaction1, Middle East: Gold Edition series published by McGraw-Hill Education, UK, have been selected for content analysis. Both male and female students from levels 3, 4 and 5 in English Department, Najran University, KSA have been selected for eliciting their opinions on the role and impact of cultural elements in selected EFL coursebooks. The groups consisted of a total of 130 students. All the questionnaires were designed and distributed by the researcher and the number of valid questionnaires found was 128 . The opinions of male and female students at different levels helped the researcher to reach a general but comprehensive conclusion. The questionnaires were translated into Arabic for the sake of clarity and easy grasp.

\section{DAta AnAlysis: TeXtbook CONTENTS}

\section{Cultural Contents in INTERACTION 1:}

A) Reading: [Elaine Kirn \& Pamela Hartmann,Middle East: Gold Edition, McGraw-Hill Education, UK, 2009]

\begin{tabular}{|l|l|l|l|l|l|}
\hline UNIT & Target Culture & Middle East Culture & Saudi Culture & International Culture & Culture Free \\
\hline Chapter 1 & & & & Education \\
\hline Chapter 2 & & & & & \\
\hline Chapter 3 & & & & Lifestyle & \\
\hline Chapter 4 & & & & Social norms & Lifestyle, Value \\
\hline Chapter 5 & & & & Lifestyle, Value & \\
\hline Chapter 6 & & Lifestyle & & Lifestyle & \\
\hline Chapter 7 & & & & & \\
\hline Chapter 8 & Lifestyle & & & & Lifestyle, Value \\
\hline Chapter 9 & Lifestyle, Value & & & & \\
\hline Chapter 10 & & & & \\
\hline
\end{tabular}

In the chart above we notice that the course book is totally devoid of Saudi culture. It contains one chapter that focuses on some aspects of Middle East lifestyle only. For example, this chapter begins with an Arabian proverb: "He who has health has hope, and he who has hope has everything". 
B) Writing: [Elaine Kirn \& Pamela Hartmann, Middle East: Gold Edition, McGraw-Hill Education, UK, 2009]

\begin{tabular}{|l|l|l|l|l|l|}
\hline UNIT & Target Culture & Middle East Culture & Saudi Culture & International Culture & Culture Free \\
\hline Chapter 1 & Education, Lifestyle & Education, Lifestyle & & Education, Lifestyle & \\
\hline Chapter 2 & Art \& culture & & & Art \& culture \\
\hline Chapter 3 & & & & Muslim Lifestyle & \\
\hline Chapter 4 & & & & Social norms \\
\hline Chapter 5 & & & & Lifestyle & \\
\hline Chapter 6 & & & & Folktales, Value \\
\hline Chapter 7 & & & & Lifestyle, habit \\
\hline Chapter 8 & Art \& Movie & & & & \\
\hline Chapter 9 & & & & Lifestyle \& Education & Sports \& Lifestyle \\
\hline Chapter 10 & & & \\
\hline
\end{tabular}

The chart above, same scenario is indicated once again. The course book is totally devoid of Saudi culture. It contains one chapter that focuses on some aspects of Middle East lifestyle only.

C) Listening and Speaking:[Elaine Kirn \& Pamela Hartmann, Middle East: Gold Edition, McGraw-Hill Education, UK, 2009]

\begin{tabular}{|l|l|l|l|l|l|}
\hline UNIT & Target Culture & Middle East Culture & Saudi culture & International Culture & Culture free \\
\hline Chapter 1 & Education, Lifestyle & & & & \\
\hline Chapter 2 & Social norms and style & & & & \\
\hline Chapter 3 & & & & Food \& Lifestyle & \\
\hline Chapter 4 & & & & Life rural and urban & \\
\hline Chapter 5 & Single life and culture & & & Culture, Lifestyle \\
\hline Chapter 6 & & & & & \\
\hline Chapter 7 & & & & & Socializing and culture \\
\hline Chapter 8 & Media and culture & & & Sports \& Lifestyle \\
\hline Chapter 9 & & & & \\
\hline Chapter 10 & & & \\
\hline
\end{tabular}

The chart above shows that the course book is totally devoid of Saudi or Middle East Culture. The lifestyle, sociocultural norms, and the idea of single life discussed in this course book clearly contradict the L1 culture and tradition.

D) Grammar: [Elaine Kirn \& Pamela Hartmann, Middle East: Gold Edition, McGraw-Hill Education, UK, 2009]

\begin{tabular}{|l|l|l|l|l|l|}
\hline UNIT & Target Culture & Middle East Culture & Saudi Culture & International Culture & Culture free \\
\hline Chapter 1 & Education, Lifestyle & & & & \\
\hline Chapter 2 & & & & Family life, adventure & Food \& Lifestyle \\
\hline Chapter 3 & & & & Social life, norms \\
\hline Chapter 4 & & & & & \\
\hline Chapter 5 & Lifestyle and culture & & & Culture, Lifestyle \\
\hline Chapter 6 & & & & & \\
\hline Chapter 7 & & & & Socializing and culture \\
\hline Chapter 8 & Media and culture & & & Customs \& Lifestyle \\
\hline Chapter 9 & & & & \\
\hline Chapter 10 & & & \\
\hline
\end{tabular}

The above chart shows again that the course book is totally devoid of Saudi or Middle East Culture. The same discussion of lifestyle, sociocultural norms, and the idea of single life contradicts the L1 culture and tradition.

2. Cultural Contents in ACCESS:

A) Reading and Writing: [Pamela Hartmann, James Mentel \& Ahmed Motala, Middle East: Gold Edition, McGraw-Hill Education, UK, 2009]

\begin{tabular}{|l|l|l|l|l|l|}
\hline UNIT & Target Culture & Middle East Culture & Saudi culture & International Culture & Culture free \\
\hline Chapter 1 & Lifestyle & & & & \\
\hline Chapter 2 & Economy & & & & \\
\hline Chapter 3 & Lifestyle & & & & \\
\hline Chapter 4 & & & & & \\
\hline Chapter 5 & Lifestyle, Value & & & & \\
\hline Chapter 6 & & & & Health \\
\hline Chapter 7 & & & & Value & \\
\hline Chapter 8 & & & & Habit & \\
\hline Chapter 9 & & & & & Dream \\
\hline Chapter 10 & & & & Travel \\
\hline
\end{tabular}

The same scenario. The chart above indicates that the course book is totally devoid of Saudi or Middle East culture. It discusses same lifestyle, sociocultural norms, and the idea of single life that contradict the L1 culture and tradition.

B) Grammar: [Milada Broukal, Middle East: Gold Edition, McGraw-Hill Education, UK, 2009] 


\begin{tabular}{|c|c|c|c|c|c|}
\hline UNIT & Target Culture & Middle East Culture & Saudi culture & International Culture & Culture free \\
\hline Chapter 1 & & Lifestyle & & Lifestyle & \\
\hline Chapter 3 & Lifestyle & & & & \\
\hline Chapter 5 & Lifestyle, Value & & & & \\
\hline Chapter 6 & Lifestyle & & & & \\
\hline Chapter 7 & Lifestyle & & & & \\
\hline Chapter 9 & Lifestyle & & & & \\
\hline Chapter 10 & Lifestyle & & & & \\
\hline Chapter 11 & & & & Lifestyle, norms & \\
\hline Chapter 12 & Lifestyle & & & & \\
\hline Chapter 13 & & & & Lifestyle & \\
\hline Chapter 14 & & & & Lifestyle, Value & \\
\hline
\end{tabular}

Almost the same scenario. The chart shows that the course book is devoid of Saudi culture except two Middle East documents. The lifestyle, sociocultural norms, and the idea of single life also contradict the L1 culture and tradition.

C) Listening and Speaking:[Emily Thrush, Robert Baldwin \& Laurie Blass

Middle East: Gold Edition, McGraw-Hill Education, UK, 2009]

\begin{tabular}{|l|l|l|l|l|l|}
\hline UNIT & Target Culture & Middle East Culture & Saudi culture & International Culture & Culture free \\
\hline Chapter 1 & & & & Lifestyle & \\
\hline Chapter 2 & Lifestyle & & & & \\
\hline Chapter 3 & Lifestyle & & & & \\
\hline Chapter 4 & & & & & Health \\
\hline Chapter 5 & Lifestyle & & & & Dream \\
\hline Chapter 6 & & & & Value & \\
\hline Chapter 7 & & & & Habit & \\
\hline Chapter 8 & & & & & \\
\hline Chapter 9 & & & & & Travel \\
\hline Chapter 10 & & & & & Environment \\
\hline
\end{tabular}

The same scenario. The chart above indicates that the course book is devoid of Saudi or Middle East culture. The lifestyle, sociocultural norms, and the idea of single life contradict the L1 culture and tradition.

Data Analysis: Questionnaire

A total of 130 questionnaires were distributed among the participants and the number of valid questionnaires found was 128. Each questionnaire includes 14 items in the form of general statements and questions.

Frequency Tables:

\begin{tabular}{|l|l|l|l|l|l|l|l|l|l|l|l|}
\hline No & Statement & \multicolumn{2}{l|}{ Strongly Agree } & \multicolumn{2}{l|}{ Agree } & \multicolumn{2}{l|}{ Not Decided } & \multicolumn{2}{l|}{ Disagree } \\
\hline & & F & P & F & P & F & P & F & P & F & P \\
\hline 1 & $\begin{array}{l}\text { Cultural discussions/illustrations are } \\
\text { important in language course books. }\end{array}$ & 55 & 43.0 & 43 & 33.6 & 19 & 14.8 & 9 & 7.0 & 2 & 1.6 \\
\hline 2 & $\begin{array}{l}\text { Only foreign cultural discussions/ } \\
\text { illustrations are offensive to L1 cultures. }\end{array}$ & 22 & 17.2 & 37 & 28.9 & 43 & 33.6 & 21 & 16.4 & 5 & 3.9 \\
\hline 3 & $\begin{array}{l}\text { I recommend only Saudi cultural } \\
\text { discussion/ illustrations in course books. }\end{array}$ & 30 & 23.4 & 56 & 43.8 & 14 & 10.9 & 20 & 15.6 & 8 & 6.3 \\
\hline 4 & $\begin{array}{l}\text { I recommend only foreign cultural } \\
\text { discussions/ illustrations in course books. }\end{array}$ & 12 & 9.4 & 16 & 12.5 & 18 & 14.1 & 56 & 43.8 & 26 & 20.3 \\
\hline 5 & $\begin{array}{l}\text { I recommend distributions of both L1 \& } \\
\text { L2 cultures. }\end{array}$ & 55 & 43.0 & 52 & 40.6 & 15 & 11.7 & 6 & 4.7 & 00 & 00 \\
\hline 6 & $\begin{array}{l}\text { I recommend equal distributions of both } \\
\text { L1 \& L2 cultures. }\end{array}$ & 20 & 15.6 & 20 & 15.6 & 17 & 13.3 & 47 & 36.7 & 24 & 18.8 \\
\hline 7 & $\begin{array}{l}\text { I recommend more L1 and less L2/foreign } \\
\text { cultures in course books }\end{array}$ & 37 & 28.9 & 66 & 51.6 & 14 & 10.9 & 8 & 6.3 & 3 & 2.3 \\
\hline 8 & $\begin{array}{l}\text { Most cultural discussions/illustrations are } \\
\text { incompatible with Saudi culture and } \\
\text { religion. }\end{array}$ & 39 & 30.5 & 66 & 51.6 & 17 & 13.3 & 5 & 3.9 & 1 & 0.8 \\
\hline 9 & $\begin{array}{l}\text { Some cultural discussions/illustrations } \\
\text { directly violate Saudi Government laws. }\end{array}$ & 37 & 28.9 & 69 & 53.9 & 16 & 12.5 & 5 & 3.9 & 1 & 0.8 \\
\hline 10 & $\begin{array}{l}\text { Some cultural discussions/illustrations } \\
\text { help us know world cultures }\end{array}$ & 46 & 35.9 & 64 & 50.0 & 15 & 11.7 & 2 & 1.6 & 1 & 0.8 \\
\hline 11 & $\begin{array}{l}\text { Learners are morally affected by } \\
\text { inappropriate L2/foreign cultures. }\end{array}$ & 42 & 32.8 & 70 & 54.7 & 10 & 7.8 & 3 & 2.3 & 3 & 2.3 \\
\hline 12 & $\begin{array}{l}\text { I recommend inclusion of L1 cultures and } \\
\text { exclusion of inappropriate L2/foreign } \\
\text { cultures }\end{array}$ & 48 & 37.5 & 67 & 52.3 & 5 & 3.9 & 6 & 4.7 & 2 & 1.6 \\
\hline
\end{tabular}




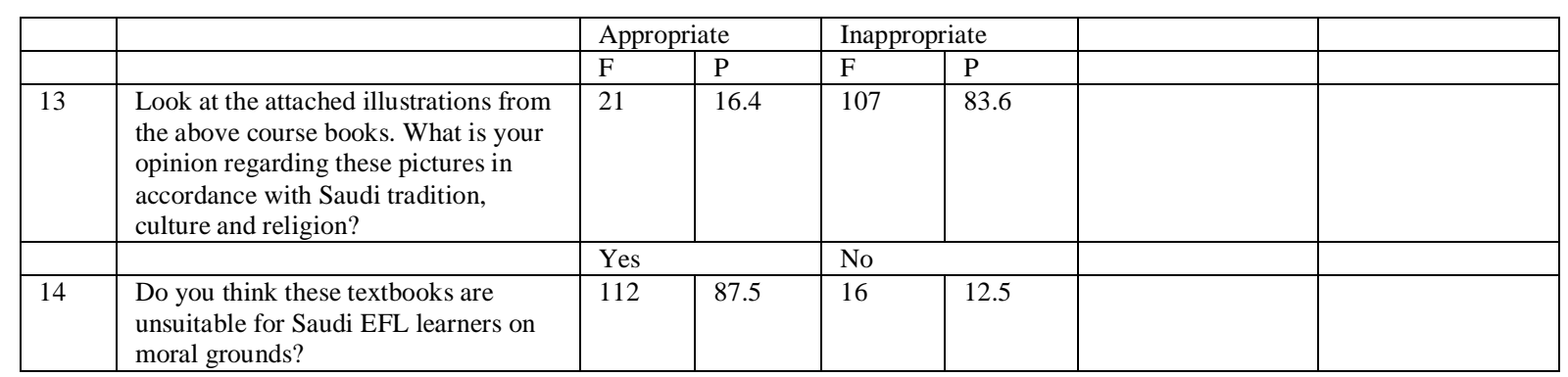

The table above shows 14 items of the questionnaire distributed to the participants and the percentages of their frequencies and opinions. For the sake of precision, the analysis of the data has been shown in three steps instead of five, i.e. Strongly Agree+ Agree as one unit, Undecided as one unit, and Strongly Disagree + Disagree as one unit with the their frequencies and percentages respectively.

In their opinion on the necessity of cultural discussions in EFL textbooks, $76.6 \%$ of the respondents believe that such discussions are beneficial to the learners, while $8.1 \%$ disagree with the view (Statement 1).However, their opinion varies on the amount and percentage of cultural items (L1 vs. L2). About 46.1\% (Statement 2) participants consider the dominance of foreign culture unfair in EFL textbooks and about 67.2\% prefer L1 culture instead of L2 (Statement 3). Students' opinion on Statement 5 in the Questionnaire indicates that they welcome a combination of both L1 and L2 cultures (83.6\%).Even, they believe that such initiatives may help them learn world culture (Statement 10; $85.9 \%$ ). However, they disagree that the distribution should be equal (Statement $6 ; 55.5 \%$ ). They, on the other hand, prefer that more L1 and less L2 cultures should be included in all EFL textbooks (Statement 7; 80.5\%).

In Section 2 of the questionnaire, students were asked about the nature and impact of the cultural contents of the selected course books on Saudi EFL learners and society. About $82.1 \%$ of the students think that the cultural discussions that they encounter in their texts contradict Saudi cultural and religious values (Statement 8). Even, 82.8\% students believe that some cultural discussions directly violate Saudi state rules (Statement 9). A huge majority (87.5\%) consider some foreign cultures as morally inappropriate and harmful to Saudi learners (Statement 11).

In Section 3, there were two attached pages. In one page, there was a picture of two young ladies in jeans and teashirts exposing the sensitive areas of their body. In the other page, there was the picture of a young lady driving a car (Question 13). The participants were asked whether those pictures were appropriate in accordance with Saudi tradition, culture and religion. Of the total respondents, $83.6 \%$ found the content of the illustrations inappropriate while $16.4 \%$ found no problem with the items. When the students were specifically asked whether they think the series prescribed for them and under our investigation is suitable for them, about $87.5 \%$ disagreed while $12.5 \%$ nodded positively.

\section{CONCLUSION AND RECOMMENDATION}

The content analysis of ACCESS and INTERACTION 1 series clearly showed that these textbooks hardly represent the Middle East cultural norms and values, let alone those of the Kingdom of Saudi Arabia. The results of the questionnaire indicated that learners' attitudes are more negative than positive to the treatment of culture. Learners believe that cultural discussions/illustrations are helpful in EFL learning, but they strongly disagree that the texts should include only foreign culture Most of the respondents have agreed with the idea that EFL textbooks should contain both L1 and L2 cultures. They also believe that such an approach help them better understand world culture and heritage.

The analysis also shows that foreign cultural contents gained significantly higher frequency than local culture. The high percentage of foreign culture is supposed to enhance the learners' knowledge of the culture of the target language. But the irony is that a low percentage of local cultural contents may pose a threat to intercultural communicative competence. As the commercial textbooks are usually written for global markets, and often do not reflect the interests and needs of students, prospects for local cultural contents are few and far between (Richards, 2001).

As for the textbook assessment, it is fundamentally subjective and it rarely provides any definite yardstick. However, such evaluative parameters may help select and design appropriate course books that best serve both principles and pedagogy. To bring about more diversity in cultural aspects, textbooks may be enriched with local features representing different classes of people, their age, work and interest. For example, a unit on food and drinks may include Khubz (big-sized baked bread), Khabsa (made of rice and chicken), Shoaiya (soft-baked chicken), and Qahwa (a traditional casual drink) instead of beef, pork, and fish served with potatoes and vegetables or dishes such as Buffalo Burger, Bull Roast, Pork and Beanor even Bubble \& Squeak and Toad-in-the -Hole accompanied by different kinds of hard drinks. Such texts may widely represent Saudi culture and tradition.

On the basis of the findings above, it may be concluded that learners have demonstrated a balanced view on the selections of cultural contents in their EFL textbooks. While about $84 \%$ students applaud an intercultural approach, almost the same overwhelming majority (84\%) demand an appropriate foreign culture that does not interfere with their local values and traditions. Moreover, while a great majority of the participants stressed the need to make sure that local values are not ignored or threatened by an upsurge of international culture, they do not invalidate the possible role of 
other cultures. The participants, however, believed local realities and scenarios should be given more priority in shaping their views than global perspectives.

This study has categorically focused on the views of the learners only. Therefore, further studies may focus on teachers' views to get a better and more comprehensive evaluation of the issue under investigation. Other issues such as local and commercial aspects of textbook may be explored. The results could be beneficial to the area of textbook editing on cultural teaching and learning. What cultural content to be included in EFL textbooks only partially focuses on the problem under discussion; the more important issue is how to select, organize and use this content in the context of a particular country, its norms, traditions and value systems. Such issues invite further investigations. The findings of this study were based on traditional printed textbooks, other types of formats like supporting electronic materials delivered by different modes of learning like Blackboard system (Mohsen \& Shafeeq, 2014) or multimedia-delivered instruction (Mohsen, 2015, 2016a, 2016b) need to be treated with from the instructors' and learners perspectives. Future studies are recommended to consider such issues to provide comprehensive results.

\section{APPENDIX. THE QUESTIONNAIRE}

\section{Department of English \\ College of Arts and Sciences \\ Najran University \\ Levels : 3 /4 /5 \\ Time: 20 minutes \\ ID-}

Programme: BA in English

Session: 1435-36

Student's Name:

[Students' attitude towards ACCESS and INTERACTION 1 gold series published for the Middle East countries, and their opinions on the illustrations/ academic discourse]

Read each item and mark $\sqrt{ }$ in the column that best expresses the level of your agreement.

L1 culture $=$ Saudi culture

L2 culture $=$ British/American/Australian cultures

Foreign culture $=$ Other countries of the world excluding the above countries

Part: A

\begin{tabular}{|c|c|c|c|c|c|c|}
\hline & & $\begin{array}{l}\text { Strongly } \\
\text { Agree }\end{array}$ & Agree & Undecided & Disagree & Strongly Disagree \\
\hline \multicolumn{7}{|c|}{ My Opinion on Culture in Course books } \\
\hline 1 & $\begin{array}{l}\text { Cultural discussions/illustrations are important in } \\
\text { language course books. }\end{array}$ & & & & & \\
\hline 2 & $\begin{array}{l}\text { Only foreign cultural discussions/ illustrations are } \\
\text { offensive to L1 cultures. }\end{array}$ & & & & & \\
\hline 3 & $\begin{array}{l}\text { I recommend only Saudi cultural discussion/ } \\
\text { illustrations in course books. }\end{array}$ & & & & & \\
\hline 4 & $\begin{array}{l}\text { I recommend only foreign cultural discussions/ } \\
\text { illustrations in course books. }\end{array}$ & & & & & \\
\hline 5 & I recommend distributions of both L1 \& L2 cultures. & & & & & \\
\hline 6 & $\begin{array}{l}\text { I recommend equal distributions of both L1 \& L2 } \\
\text { cultures. }\end{array}$ & & & & & \\
\hline 7 & $\begin{array}{l}\text { I recommend more L1 and less L2/foreign cultures in } \\
\text { course books }\end{array}$ & & & & & \\
\hline
\end{tabular}

Part: B

\begin{tabular}{|c|c|c|c|c|c|c|}
\hline & & $\begin{array}{l}\text { Strongly } \\
\text { Agree }\end{array}$ & Agree & Undecided & Disagree & $\begin{array}{l}\text { Strongly } \\
\text { Disagree }\end{array}$ \\
\hline \multicolumn{7}{|c|}{$\begin{array}{l}\text { My Opinion on INTERACTIONS } 1 \text { and ACCESS Middle East gold edition series } \\
\text { in Saudi Cultural and Religious context. }\end{array}$} \\
\hline 1 & $\begin{array}{l}\text { Most cultural discussions/illustrations are incompatible with Saudi culture } \\
\text { and religion. }\end{array}$ & & & & & \\
\hline 2 & $\begin{array}{l}\text { Some cultural discussions/illustrations directly violate Saudi Government } \\
\text { laws. }\end{array}$ & & & & & \\
\hline 3 & Some cultural discussions/illustrations help us know world cultures & & & & & \\
\hline 4 & Learners are morally affected by inappropriate L2/foreign cultures. & & & & & \\
\hline 5 & $\begin{array}{l}\text { I recommend inclusion of L1 cultures and exclusion of inappropriate } \\
\text { L2/foreign cultures }\end{array}$ & & & & & \\
\hline
\end{tabular}

\section{Part C}

1. Look at the attached illustrations from the above course books. What is your opinion regarding these pictures in accordance with Saudi tradition, culture and religion? 
a) Appropriate

b) Inappropriate

2. Do you think these textbooks are unsuitable for Saudi EFL learners on moral grounds? Yes

No

\section{REFERENCES}

[1] Al-Houssawi, H. (2010). The non-native English teachers' perceptions about the presented cultural values and traditions in North Star English Textbook in Saudi Arabia. Critical Issues in TESOL. Unpublished E dD. University of Exeter.

[2] Abuelma'ati, Z. (2005). Translation and cultural representation: Globalization of texts, localizing cultures. Unpublished PH D thesis. University of Salford. Salford: UK.

[3] Ayubi, N. (1994). Polotical Islam: Religion and politics in the Arab world. London: Routeledge

[4] Block, D. and D. Cameron (eds.) (2002). Globalization and Language Teaching. London: Routledge.

[5] Brumfit, C. J. (1980). Seven last slogans. Modern English Teachers, 7/1, 30-31.

[6] Cunningsworth, A. (1995). Choosing your coursebook. London: Macmillan: Heinemann.

[7] Gray, J. (2006). A study of cultural content in the British ELT global coursebook: A cultural studies approach. Unpublished Ph D thesis. Institute of Education, University of London.

[8] Hajjaji, A. S. (1981). English language teaching in Kuwait. Teaching English Abroad Newsletter.

[9] Hornby, A S. (2010). Oxford Advanced Learner's Dictionary. Oxford. Oxford University Press.

[10] Hyde, M. (1994). The teaching of English in Morocco: the place of culture. ELT Journal 48/4: 295-305.

[11] Hayes, N. \& Schrier, L. (2000). Encouraging second language literacy in the early grades. Hispania, 83(2), 286-296.

[12] Kaikkonen, P. (1994). Kulttuuri ja vieraan kielen oppiminen. Helsinki: WSOY.

[13] Mohsen, M., \& Shafeeq, C. P. (2014). EFL Teachers' Perceptions on Blackboard Applications. English Language Teaching, 7(11), 108-118. Retrieved on July, 2016 from http://dx.doi.org/10.5539/elt.v7n11p108.

[14] Mohsen, M. A. (2015). The use of help options in multimedia listening environments to aid language learning: a review. British Journal of Educational Technology. DOI: 10.1111/bjet.12305.

[15] Mohsen, M. A. (2016a). The Use of Computer-Based Simulation to Aid Comprehension and Incidental Vocabulary Learning. Journal of Educational Computing Research, DOI: 0735633116639954.

[16] Mohsen, M. A. (2016b). Effects of help options in a multimedia listening environment on L2 vocabulary acquisition, Computer Assisted Language Learning, DOI: 10.1080/09588221.2016.1210645.

[17] Nault, D. (2006). Going Global: Rethinking Culture Context in ELT Contexts. Language, Culture and Curriculum. 19(3), $314-$ 328.

[18] Nieto, S. (2010). Language, Culture, and Teaching. Critical perspectives. New York: Routledge.

[19] Nunan, D. (1988). Learner-Centered Curriculum. Cambridge: Cambridge University Press.

[20] Pennycook, A. (1994). The cultural politics of English as an International Language. London \& New York: Longman.

[21] Philipson, R. H. L. (1992). Linguistic Imperialism. Oxford: Oxford University Press.

[22] Prodromou, L. (1988). English as cultural action. ELT Journal 42/2: 73-83.

[23] Richards, J. C. (2001). Curriculum development in language teaching. Cambridge: Cambridge University Press.

[24] Scott, C. S. (1980). Some first impression of EFL teaching in China. TESOL Newsletter. 14/6, 113-43.

[25] Tomlison, B. et al. (2001). ELT courses for adults. ELT Journal, 55(1), 80-101.

\footnotetext{
Abdullah Saad Aldera is an associate professor of applied linguistics in the Department of English, Najran University. Currently, he is working as the dean of College of Arts and Science, Najran University, Saudi Arabia. He has published several papers in refereed international journals indexed in SSCI and Scopus. His research interest is second language acquisition, mother tongue interference, and computer assisted language learning (CALL).
} 